\title{
САМОМЕНЕДЖМЕНТ ЯК ЗАСІБ ПРОФЕСІЙНОГО РОЗВИТКУ МАЙБУТНІХ УЧИТЕЛІВ
}

Дуднік Н. Ю. Самоменеджмент як засіб професійного розвитку майбутніх учителів.

У статті розглянуто сутність поняття «самоменеджмент» у сучасній літературі, з'ясовано його роль у професійному розвитку особистості, наведено результати дослідження з виявлення значущості навичок самоуправління для майбутніх учителів. У статті наголошується на необхідності формування у студентів навичок самоменеджменту задля професійного становлення і розвитку.

Ключові слова: самоменеджмент, навички самоуправління, професійний розвиток, майбутні вчителі.

Дудник Н. Ю. Самоменеджмент как средство профессионального развития будущих учителей.

В статье рассмотрена суть понятия «самоменеджмент» в современной литературе, определена его роль в профессиональном развитии личности, приведены результаты исследования по выявлению значимости навыков смоуправления для будущих учителей. В статье подчеркивается важность формирования у студентов навыков самоменеджмента с целью профессионального становления и развития.

Ключевые слова: самоменеджмент, навыки самоуправления, профессиональное развитие, будущие учителя.

Dudnik N. Yu. Self-management as a means of professional development of future teachers.

The article deals with the essence of the concept of «Self-management» in modern literature and determines its role in the professional development of the individual; the results of research to identify the importance of self-management skills for future teachers are exemplified. The article emphasizes the need to develop students' skills of self-management for professional formation and development.

Key words: self-management, skills of self-management, professional formation, future teachers.

Проблема вдосконалення педагогічного професіоналізму вчительських кадрів належить до актуальних питань сьогодення. Від професійної майстерності, ерудиції та рівня педагогічної культури вчителя залежить виховання молодого покоління. Сучасній школі потрібний не виконавець професійних функцій, а творчий учитель, здатний уміло організувати життя та діяльність дитячого колективу, готувати учнів до життя в нових економічних умовах [9, с. 92].

Успішне розв'язання цих та інших питань залежить від рівня професіоналізму вчителя, а професійний розвиток - це прерогатива кожної конкретної людини.

У сучасному світі, який швидко змінюється, перевага надається не послідовній зміні посад в одній ієрархії, а зміні позицій у різних проектах. У цих умовах такі традиційні елементи процесу формування і розвитку професіоналізму, як вища освіта, посадове просунення, підвищення кваліфікації втрачають своє значення. Роботодавця більше цікавить результат, якого може досягти спеціаліст, а не його диплом. Тому виникає необхідність говорити не про кар'єру, а про трудовий шлях, професійну долю людини, яка може бути різною: щасливою, важкою, успішною, вона може скластися або ні.

«Що потрібно для того, щоб трудовий шлях був вдалим?»- питання, яке постає перед кожною людиною. «Щоб досягти успіху, потрібно вміти керувати собою» - зазначає Х. Швальбе [6, с. 4 ].

Необхідність розв'язання проблеми управління вперше виникла в економіці, але згодом термін «менеджмент» набув широкого вжитку й у сфері соціальних і політичних відносин. Це пояснюється тим, що менеджмент поширений скрізь, де має місце будь-яка діяльність [ 1, с. 18]. Залежно від сфери дії, виокремлються різні види менеджменту: загальний, або адміністративний, галузевий, організаційний, функціональний, підприємницький, кадровий тощо [1, с. 19]. Останнім часом науковці виокремлюють ще один вид - педагогічний менеджмент.

Проблема організації педагогічного менеджменту вважається науковцями однією 3 пріоритетних, водночас малодосліджених у педагогічній науці. Великий внесок у її розв'язання 
зробили зарубіжні та вітчизняні науковці Ф.Тейлор, М. Райс, Х. Швальбе, І. Зязюн, Л. Кондрашова, С. Мартинов, В. Маслов, Г. Сагач, В. Шаркунова та інші.

Більшість науковців вважають, що менеджмент - це система планування, організації, мотивації та контролю, необхідна для визначення та досягнення цілей організації.

Педагогічний менеджмент, як зазначають Б. Дьяченко та Т. Сорочан, $є$ комплексом принципів, методів, організаційних форм і технологічних прийомів управління освітнім процесом, спрямованого на підвищення його ефективності [9, с. 93].

Необхідність виокремлення педагогічного менеджменту як галузі загальної науки управління зумовлена професійними особливостями роботи вчителя. Адже кожний учитель має декілька класів, паралелей, у яких навчаються дуже різні учні. Саме вчитель $є$ керівником й організатором життя і діяльності учнів, він повинен готувати їх до життя в нових економічних умовах, бачити закладені в них резерви, допомагати їм оцінити себе, щоб зробити крок у саморозвитку.

Організовуючи життя школярів, учитель повинен, передовсім, уміти правильно організувати власну діяльність. Для цього, на нашу думку, потрібно вміти управляти собою та виявляти свої сильні та слабкі сторони, раціонально використовувати час, мати чіткі цінності та цілі, вміти обробляти та використовувати інформацію, прагнути до саморозвитку, мати навички самостійного розв'язання нагальних питань та впливу на людей, уміти формувати колектив та запобігати конфліктам. Комплекс зазначених професійно-особистісних якостей характеризує рівень професійної компетентності педагога. Підвищити рівень власного професіоналізму кожна людина може самостійно, завдяки самоменеджменту - складній роботі над собою, що потребує поступовості, систематичності, послідовності, самокритичності та самоконтролю.

Meта статті - розглянути сутність поняття «самоменеджмент» у сучасній літературі, з'ясувати його роль у професійному розвитку особистості та встановити значущість навичок самоуправління для майбутніх учителів.

Самоменеджмент як новий напрямок дослідження виник наприкінці XX століття в сучасному менеджменті внаслідок психологізації та соціологізації як відповідь на потреби суспільства більш повно використовувати та розвивати творчий потенціал робітників [6, с. 19]. Досліджували питання самоменеджменту Л. Зайверт, М. Вудкок, Д. Френсіс, В. Андреєв, Н. Лукашевич, В. Крижко, С. Павлютенков та інші.

У зв'язку з тим, що проблема самоменеджменту лише нещодавно стала об'єктом наукових досліджень, ще не існує єдиного визначення цього складного поняття.

Так, наприклад, Л. Зайверт (автор терміна «самоменеджмент») визначає його як послідовне і цілеспрямоване використання випробуваних методів роботи в повсякденній практиці для оптимального використання свого часу [2].

Російський соціолог В. Оглоблін розглядає самоменеджмент як цілеспрямоване й послідовне використання практичних методів управління в повсякденній діяльності задля оптимізації використання своїх персональних ресурсів: інтелекту, волі, здібностей тощо [7].

М. Лукашевич подає таке визначення самоменеджменту: «послідовне і цілеспрямоване використання ефективних методів, прийомів та технологій самореалізації і саморозвитку свого творчого потенціалу» [ 6 ].

В. Крижко та Є. Павлютенков підкреслюють, що самоменеджмент - це система визначених та саморегульованих заходів, спрямованих на підвищення ефективності професійної діяльності й самовдосконалення особистісних якостей [4]. Цікавим є зіставлення цього визначення 3 тлумаченням поняття «педагогічний розвиток», запропонованим цими ж авторами: «професійний розвиток (у педагогічній діяльності) - це набуття педагогічними працівниками нового рівня компетенції, знань, умінь, навичок, які вони використовують у своїй професійній діяльності; процес формування у педагогічних працівників нових професійних навичок i знань» [4, с. 283]. Аналіз визначень дозволяє зробити висновок, що самоменеджмент $є$ необхідною умовою професійного розвитку людини.

Проаналізувавши наведені визначення, можна зробити висновок, що самоменеджмент - це поступова, систематична і послідовна робота, спрямована на самовдосконалення особистісних якостей, розвиток творчого потенціалу та підвищення ефективності професійної діяльності особистості незалежно від віку та професійної спрямованості. 
Задля з'ясування рівня значущості проблеми самоменеджменту для студентів вищої школи серед студентів Криворізького педагогічного інституту було проведено опитування. У дослідженні брали участь студенти I, III та V курсів.

Передовсім, слід зазначити, що переважна більшість студентів різних курсів не змогла відповісти на питання «Що таке самоменеджмент?», тому в нашому дослідженні ми використовували термін «самоуправління». Результати дослідження наведено нижче.

Як Ви оцінюєте власний рівень самоуправління? (\%)

\begin{tabular}{|l|l|l|l|l|}
\hline курс & високий & скоріше високий, ніж низький & скоріше низький, ніж високий & низький \\
\hline
\end{tabular}

\begin{tabular}{|c|c|c|c|c|c|}
\hline $\mathrm{I}$ & 21,6 & 63,3 & 10 & 0 & 5,1 \\
\hline $\mathrm{III}$ & 11 & 58 & 0 & 11 & 20 \\
\hline $\mathrm{V}$ & 44 & 42 & 6 & 0 & 8 \\
\hline
\end{tabular}

Порівняльний аналіз відповідей респондентів різних курсів свідчить, що більшість опитаних уважають свій рівень самоуправління скоріше високим, ніж низьким. При цьому студенти III курсу найбільш самокритичні. Всього $11 \% 3$ них уважають свій рівень самоменеджменту високим, тоді як кількість студентів V курсу, що дотримуються аналогічної думки, складає 44\%. Низьким свій рівень самоуправління найбільш об'єктивно вважають студенти III курсу (11\%).

Які з перелічених навичок самоуправління Ви вважасте найбільш важливими? (\%)

\begin{tabular}{|l|c|c|c|c|c|c|}
\hline курс & самооцінка & самопланування & самоорганізація & самоконтроль & самомотивація & інше \\
\hline $\mathrm{I}$ & 40 & 23 & 63,3 & 45 & 21 & 10 \\
\hline $\mathrm{III}$ & 22 & 38 & 50 & 33 & 11 & 0 \\
\hline $\mathrm{V}$ & 26 & 22 & 58 & 16 & 18 & 2 \\
\hline
\end{tabular}

Одним із найбільш важливих питань $є$ виявлення тих якостей, які відбивають здатність особистості до самоменеджменту. Безумовну першість займає самоорганізація (I курс - 63,3\%, III курс $-50 \%$, V курс - 58\%). Заслуговує на увагу той факт, що для студентів старших курсів зменшується значущість самоконтролю (від 45\% серед студентів I курсу до $16 \%$ серед студентів старших курсів). Першокурсників більше турбує самооцінка (40\%) і самомотивація (21\%). У той же час до структурування власних планів більше схильні студенти III курсу (38\%).

На якому етапі професійного розвитку, на Вашу думку, виникає необхідність у самоуправлінні? (\%)

\begin{tabular}{|l|c|c|c|c|c|l|}
\hline курс & $\begin{array}{c}\text { при виборі } \\
\text { професії }\end{array}$ & $\begin{array}{c}\text { при праце- } \\
\text { влаштуванні }\end{array}$ & $\begin{array}{c}\text { у процесі посадового } \\
\text { розвитку }\end{array}$ & $\begin{array}{c}\text { під час переходу з } \\
\text { однісї посади на іншу }\end{array}$ & $\begin{array}{c}\text { у процесі підви- } \\
\text { щення кваліфікації }\end{array}$ & інше \\
\hline I & 45 & 15 & 28,3 & 5 & 12 & 10 \\
\hline III & 22 & 16,5 & 22 & 5,7 & 0 & 5,7 \\
\hline $\mathrm{V}$ & 24 & 24 & 40 & 6 & 16 & 6 \\
\hline
\end{tabular}

Студенти-п’ятикурсники необхідність планування на всіх етапах розвитку кар'єри розуміють краще, ніж респонденти інших груп. Найбільш актуальним для представників старших курсів $\epsilon$ планування посадового розвитку (40\%). Під час вибору професії планування найбільш значущим $\epsilon$ для студентів I курсу (45\%). Ці результати свідчать про необхідність упровадження спеціальних навчальних дисциплін, орієнтованих на розвиток самоменеджменту студентів.

Де, на Ваш погляд, потрібно отримувати знання і навички самоуправління? (\%)

\begin{tabular}{|c|c|c|c|c|c|}
\hline курс & у школі & В ВН3 & на роботі & самостійно & інше \\
\hline I & 50 & 33 & 20 & 30 & 5 \\
\hline III & 5,7 & 33 & 16,5 & 27 & 11 \\
\hline V & 36 & 20 & 20 & 30 & 20 \\
\hline
\end{tabular}

Необхідність отримання знань та навичок самоуправління у школі зазначають $50 \%$ респондентів серед першокурсників. До їх оцінки близькі представники V курсу (36\%). Необхідність оволодіння уміннями самоменеджменту у вищому навчальному закладі визнають опитані студенти усіх курсів $(33 \%, 33 \%, 20 \%$ відповідно). У той же час майбутні учителі підкреслюють необхідність самоосвіти (30\%, 27\%, 30\% відповідно).

Наведені дані свідчать про необхідність формування у студентів вищої школи умінь самоменеджменту (самопізнання, самовизначення, самоорганізації, самоконтролю, самооцінки, саморозвитку тощо), що забезпечить успішне розв'язання більшості проблем керування собою, 
формування чітких особистісних цілей, раціонального використання свого часу, кваліфікованого опрацювання та використання інформації.

У процесі розвитку у студентів почуття професійної гідності, відповідальності та компетентності у розв'язанні професійних задач велику роль відіграє можливість активної участі у створенні програми власного професійного розвитку, прийнятті рішень, які стосуються власної освіти, організації навчальної та науково-дослідницької діяльності. Водночас із розв'язанням навчальних проблем майбутній фахівець повинен мати змогу акцентувати власні зусилля на саморозвиток та самоствердження, вдосконалення професійних здібностей, становлення професійної самосвідомості [3, с. 7].

Організація навчального процесу у вищій школі покликана сприяти постійному перетворенню особистісно-суспільних цілей у дієвий внутрішній стимул професійного становлення студентів, закріплення та розвиток активної професійної позиції і творчого стилю діяльності [ 3, с. 8].

У кожної людини є нереалізований потенціал. Безумовно, наявні межі індивідуальних можливостей: вік, здоров'я, сімейна ситуація, освіта тощо. Але якщо людина спробує хоча б частково подолати ці обмеження, які заважають ії розвитку, то можна переконатися, що багато 3 них лише здаються незборимими. Як казав В. Джеймс, «серед усіх створінь, які живуть на Землі, лише людина може змінити себе» [4, с. 10].

Отже, актуальною проблемою сьогодення є формування творчої та високо професійної особистості вчителя, який вміє керувати собою за будь-яких обставин. Результати проведеного опитування серед студентів педагогічного інституту зумовлюють необхідність формування в майбутніх учителів грунтовних знань та умінь самоуправління.

Лiтература
1. Завадський Й. С. Менеджмент: Management / Й. С. Завадський - К. : Українсько-фінський інститут менеджменту і бізнесу, 1997. - 543 с. 2. Зайверт Л. Ваше время - в ваших руках:[ пер. с нем.] / Л. Зайверт. - М. : Экономика, 1991. - 125 с. З. Кондрашова Л. В. Формування професійного «я» майбутніх педагогів засобами особистісно зорієнтованого навчання в практиці вищої школи / Л. В. Кондрашова // Педагогіка вищої та середньої школи. - Кривий Ріг, 2000. - Вип. 2. - С. 3-13. 4. Крыжко В. В. Психология в практике менеджера образования /
В. В. Крыжко, Е. М. Павлютенков. - СПб. : КАРО, 2002. - 304 с. 5. Латыпова М. Школьный менеджмент: модное слово или путь к совершенствованию? / М. Латыпова // Народное образование. - 2000. - № 1. - С. 76 83. 6. Лукашевич М. П. Теорія і практика самоменеджменту: [навч. посіб.] / М. П. Лукашевич. - К. : МАУП, 1999. - 360 с. 7. Оглоблин В. Персональный менеджмент - основа успешной карьеры // Управление персоналом. - 2004. - №14. - С. 5-8. 8. Рибалкін В. О. Основи економічної теорії: [посіб. для студ. вищ. навч. закл.] / В. О. Рибалкін, М. О. Хмелевський, Т. І. Біленко. - К. : ВЦ «Академія», 2002. - 352 с. 9. Штельмах Г. Б. Принцип гуманізації та психологізації педагогічного менеджменту як основа реалізації особистісно-орієнтованого навчання під час процесу професійної перепідготовки педагогічних кадрів / Г. Б. Штельмах, О. Б. Поліщук // Педагогіка вищої та середньої школи. - Кривий Ріг, 2004, - Вип. 7. - С. 92-96.

УДК 378.147

Вероніка Сгорова

\section{ІНФОРМАЦЙНО-ТЕХНОЛОГІЧНА КЛЮЧОВА КОМПЕТЕНТНІСТЬ ВИКЛАДАЧІВ ІНОЗЕМНИХ МОВ ВНЗ ЯК НЕОБХІДНА УМОВА ЇХНЬОГО ПРОФЕСІЙНОГО РОЗВИТКУ}

Єгорова В. В. Інформаційно-технологічна ключова компетентність викладачів іноземних мов ВНЗ як необхідна умова їхнього професійного розвитку.

Статтю присвячено аналізу й обгрунтуванню складників інформаційно-технологічної ключової компетентності викладачів іноземних мов ВН3 та ії характеристик, практичному впровадженню результатів теоретичного дослідження.

Ключові слова: ключові компетентності, інформаційно-технологічна ключова компетентність, викладачі іноземних мов ВНЗ, науково-педагогічні працівники.

Егорова В. В. Информационно-технологическая ключевая компетентность преподавателей иностранных языков вузов как необходимое условие их профессионального развития.

Статья посвящена анализу и обоснованию составляющих информационно-технологической 